Jahangirnagar University J. Biol. Sci. 9(1 \& 2): 35-48, 2020 (June \& December)

\title{
Population status and feeding behavior of black kite (Milvus migrans) in Dhaka city, Bangladesh
}

\author{
Md. Amdadul Haque*, Rasel Ahammed ${ }^{1}$, Monirujjaman, Md. Abraharul Islam, \\ Md. Nahid H. Khan, Syed A. Rayan, M. Monirul H. Khan and Md. Mofizul Kabir \\ Department of Zoology, Jahangirnagar University, Savar, Dhaka-1342, Bangladesh
}

\begin{abstract}
The status and feeding behavior of black kite (Milvus migrans) in Dhaka city were studied from July 2015 to June 2017. Road transects and morning roost-count method were used for population estimation and distribution, whereas focal sampling method was used to study the feeding and foraging behavior. Based on roosting and foraging areas, five transects were selected for population estimation. Moreover, six different feeding areas were selected for identifying various types of consumed food and assessing the feeding behavior of black kite. The black kite population was estimated at $(1296 \pm 5.87)$ in Dhaka city. The population density was estimated at $21.8 / \mathrm{km}^{2}$. Among selected five different transects, the recorded population ranged from $108.12 \pm 6.70,8.34 \%$ ) at S-3 (Mirpur to Ramna Park) to $805 \pm 11.88,62.11 \%$ of individuals at S-5 (Gulistan to Demra). The present study revealed that black kites were distributed throughout the study area and the distribution was influenced by availability of food, water and roosting place. Based on the annual records, the highest population (1510 \pm 6.92$)$ was found in 2016. Majority of black kites fed on offal and insects in study area. In garbage dumps, the highest rate of feeding was recorded in afternoon followed by in morning and lowest in the noon. Whereas in non-garbage feeding areas, the highest rate was recorded in the morning followed by in the afternoon and lowest in the noon. Among four different foraging strategies, food collection by kites standing on the ground and intraspecific cleptoparasitism was never observed during study period while interspecific cleptoparasitism (against crows) was the highest number $(193.67 \pm 2.77,68.43 \%)$.
\end{abstract}

Key words: Black kite, Population, Feeding, Cleptoparasitism, Dhaka city.

\section{INTRODUCTION}

Birds of prey are hard to study in the field as they occupy wide home ranges and often inhabit distant pathless regions (Fuller \& Mosher, 1981). The black kite (Milvus migrans) is an Accipitrid and broadly distributed in the Old World (Gupta et al., 2011). Moreover, their density exhibits local and seasonal fluctuations and their activity may vary throughout the day (Newton, 1979). Accurate estimates of their population can be made by conducting surveys in these sites during certain months of the year and times of the day (Taylor, 1983). In addition, improved monitoring techniques consist of counting birds at their breeding or roosting sites early in the morning or late in the evening before or after their daily foraging trips (Robertson \& Boshoff, 1986; Meyer, 1998; Mazumdar et al., 2017, 2018). The black kites often gather in large communal roosts and breeding colonies. Large aggregations also occur where food is abundant and during migration

${ }^{1}$ IUCN, Mohakhali DOHS, Dhaka-1206, Bangladesh.

*Corresponding author. E-mail: amdadulhaqueju@ gmail.com 
(Cramp \& Simmons, 1980). As scavenging raptors, frequently take advantage from human waste worldwide (Pomeroy, 1975; Blanco, 1994 and 1997). The black kite is known to be a gregarious bird (Cramp \& Simmons, 1980) that opportunistically disperse a large array of food sources (Delibes, 1975). Despite the widespread range and abundance of the black kite, limited information is available concerning the proportion of age classes in resident groups and in migration (Cramp \& Simmons, 1980). Knowledge about the age distribution of kites using rubbish dumps, and the timing of residency and migration associated with these sites is almost nonexistent (Pomeroy, 1975). To the best of our knowledge this is the first report of field level research carried out in Bangladesh. Studies on the status and feeding behavior of black kites in Dhaka city is almost nonexistent as per our knowledge goes. The objective of the present study was to - (a) estimate the population and distribution of black kites in Dhaka city, (b) identify the types of food consumed by the black kites in study area, (c) assess the behavioral strategies of black kites to collect food from the selected feeding areas and (d) determine the food consumption rate per day.

\section{MATERIALS AND METHODS}

Study Area: The black kites were studied in Dhaka city $\left(23^{\circ} 81 \mathrm{~N}, 90^{\circ} 41 \mathrm{E}\right)$, in a 306.4 $\mathrm{km}^{2}$ area of Dhaka district. The average annual temperature is $25^{\circ} \mathrm{C}$ and the average annual percentage of humidity is $74 \%$. Five sites were selected for population estimation and distribution based on road transect and roost counting methods (Table 1) and six different foraging areas were selected for identification various types of foods consumed by black kites and assessments of feeding behavior in study area. The list of foraging area are- (A) dumping site behind Kachukhet market (B) Boliarpur dumping station (C) dumping site behind Abdullahpur market (D) agricultural field, bank of Buriganga river (E) National botanical garden, Mirpur and (F) human habitation in and around Dhaka city which marked as location A (L-A) to location F (L-F) subsequently for the convenience of the study.

In the area of Dhaka city, five transects were determined and designated as Transect-1 (T1), Transect-2 (T-2), Transect-3 (T-3), Transect-4 (T-4) and Transect-5 (T-5) for the convenience of the study. Transect-1 located north-west part of the study area besides Turag River. Transect-2 located south-west part of the study area on the bank of Buriganga River. Transect-3 situated middle (east to west) part of the study area. Transect-4 located northeast part of the study area behind Hazrat Shahjalal International Airport. Transect-5 located southeast part of the study area.

Meteorological parameters: Among the observed meteorological parameters during the study period significant fluctuations of the temperature were found over the year in the studied area. The mean temperature in study area was $(33 \pm 2)$ centigrade in summer, $(29 \pm 0.46)$ in monsoon, while $(18 \pm 1.5)$ in winter. Highest humidity levels occurred in monsoon $(82.5 \pm 3.1 \%)$ while lowest in summer $(68.25 \pm 4 \%)$ and in winter mean humidity levels were $(73.75 \pm 0.8 \%)$. In the area of Dhaka city, rains occur only in monsoon during the study period. Hence, the mean rainfall in monsoon was $(333 \pm 0.3 \mathrm{~mm})$. 
Table 1. Name of five transects with their length in Dhaka city

\begin{tabular}{c|l|c|c|c|c}
\hline SI. & \multicolumn{1}{c|}{ Transects Name } & $\begin{array}{c}\text { Length of } \\
\text { Transect } \\
(\mathrm{km})\end{array}$ & $\begin{array}{c}\text { Feeding } \\
\text { sites }\end{array}$ & $\begin{array}{c}\text { Roosting } \\
\text { sites }\end{array}$ & $\begin{array}{c}\text { Breeding } \\
\text { sites }\end{array}$ \\
\hline 1 & $\begin{array}{l}\text { Gabtali Bus Terminal, Beribadh to } \\
\text { Abdullahpur. }\end{array}$ & 6 & 2 & - \\
2 & $\begin{array}{l}\text { Gabtali Sweeper Colony, Gabtali- } \\
\text { Sadarghat rd to Dhaka University. } \\
3\end{array}$ & $7.3 \mathrm{~km}$ & 4 & 2 & 1 \\
$\begin{array}{l}\text { Mirpur 1, Sangsad Bhaban, Tejgaon } \\
\text { to Ramna Park. }\end{array}$ & $10 \mathrm{~km}$ & 3 & 1 & - \\
4 & $\begin{array}{l}\text { Uttara, Kuril to Mohakhali Bus } \\
\text { Terminal. }\end{array}$ & $15.1 \mathrm{~km}$ & 3 & 1 & 2 \\
\hline & $\begin{array}{l}\text { Gulistan to Demra dumping station. } \\
\text { Total }\end{array}$ & $9 \mathrm{~km}$ & 2 & 1 & 4 \\
\hline
\end{tabular}

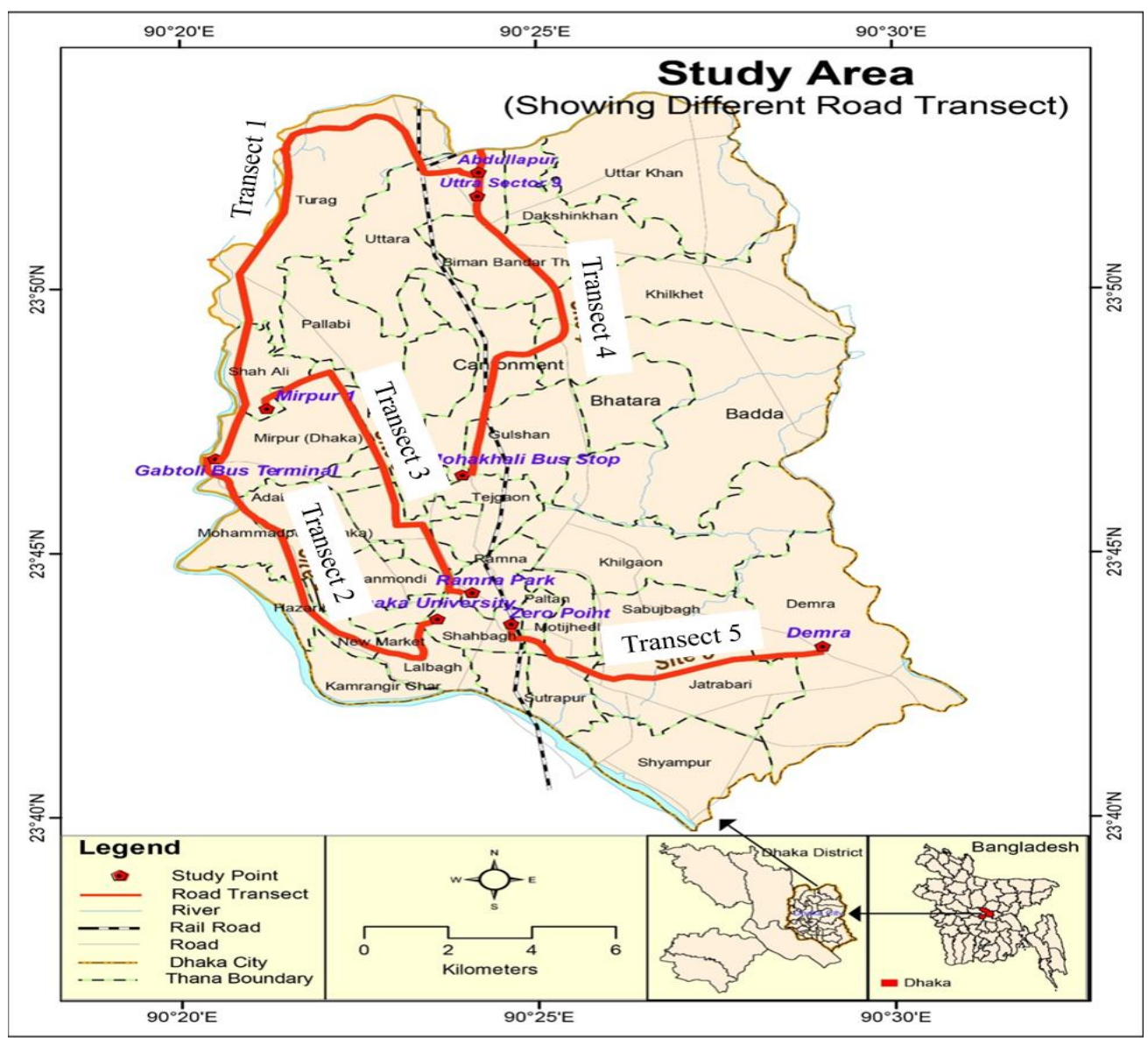

Fig. 1. Map of study area (Dhaka city) showing different road transect locations in red lines 
Data sampling: The study was conducted between July 2015 and June 2017 in Dhaka city. At the very beginning of the present study, transect and various foraging sites were selected through visiting different areas. Road transects seem to be a reliable method to estimate the numbers of kites (Viñuela, 1997). For population estimation, road transect and morning roost-count methods was used (Fuller \& Mosher, 1987; Ethier, 1993; Mazumdar, 2013; Mazumdar et al., 2017, 2018) and to study various feeding and foraging behavior focal sampling method was used (Altman, 1974; Sharma \& Soni 2017). Based on roosting and foraging area, five sites were selected for population estimation, covering a total length of $59.5 \mathrm{~km}$ (Table 1), which cover approximately entire Dhaka city. The fixed transect width was taken at $50 \mathrm{~m}$ from both sides of the transect. In the foraging sites, counting was started from dawn when kites were coming in foraging area and conducted simultaneously at the same time at selected sites. Eight counting trips were made at each site during the study period for population estimation. To aid in counting, binocular and Canon 60D camera were used. Observations were made from elevated sites with the help of a binocular (Olympus 10×50) at the distance of about 40 metre from the roosts to avoid interruption of the kites behavior. Photographs were also taken while flying to avoid overlapping because the kites often fly away after watching the observers. While counting sighting places were distinguished into following activity: 1) when feeding; 2) when roosting; 3) when flying; 4) when breeding. Food collecting strategies were distinguished as: 1) directly from the feeding area by an individual standing on the ground; 2) while flying over the feeding habitat; 3) through intraspecific cleptoparasitism (when an individual snatch food from another individual of same species): 4) through interspecific cleptoparasitism (when the Black Kites snatch food from the individuals of different species) (De Giacomo \& Guerrieri, 2008, Mazumdar et al., 2016). Actively feeding individual was selected as a focal bird and attempts were made to cover different individuals found in various feeding sites. During observation of feeding behavior, three counting trips were made at each site. To determine food consuming rate in a day, data was pooled into three time slots: morning (6:00am-10:00am), noon (10:00am-2:00pm) and afternoon (2:00pm-6:00pm). A timed-count method was employed to determine food taking rate in a day. The populations densities can be calculated by dividing the total number of individuals in transects with the total transect area surveyed. The results were compared across the years to understand the trend of population densities. Weather data were collected from Bangladesh Meteorological Department, Dhaka (www.bmd.gov.bd).

Statistical analysis: Multiple linear regression was used to correlate black kite population in Dhaka city with different activity (flying, roosting, feeding, breeding), annual fluctuation $(2015,2016,2017)$ and seasons. Data was gathered into three seasons: summer (February-May), monsoon (June-September) and winter (October-January). Multiple linear regression was also used to test the effects of environmental parameters (temperature and humidity) on the population's fluctuation and feeding behavior of black kites. Values are expressed as mean $( \pm$ SE) and the results were considered significant at $\mathrm{P}<0.05$. Analyses were done using SPSS 16.0 software (Daniel, 2014; Mazumdar, et al., 2016). Regression was employed to seasonal relationship between mean numbers of successful feeding as dependent variables and environmental parameters like temperature and humidity as independent variables. 


\section{RESULTS AND DISCUSSION}

Population estimation: Black kite population in Dhaka city comprise of $1296 \pm 5.87$ individuals (Table 2). The population density was estimated at $21.8 / \mathrm{km}^{2}$. Among selected five different transects, the highest record of kites population $(805 \pm 11.88)$ was found at Transect-5 (Gulistan to Demra dumping station) while the lowest population was recorded at Transect-4 (Uttara, Kuril to Mohakhali Bus Terminal) (Table 2). The mean values of the population of black kites at selected sites showed the following order Transect-1 (Gabtali Bus Terminal, Beribadh to Abdullahpur) > Transect-3 (Mirpur 1, Sangsad Bhaban, Tejgaon to Ramna Park) > Transect-2 (Gabtali Sweeper Colony, Gabtali-Sadarghat rd to Dhaka University). It was also found in the study period that flying was the most observed activities in black kite followed by roosting, feeding and breeding (Table 2). Different activities such as flying $\left(R^{2}=0.97\right)$, roosting $\left(R^{2}=0.95\right)$ and feeding $\left(R^{2}=0.95\right)$ are significantly correlated with the number of black kites while breeding was not significantly related with their abundance (Table 3). Both temperature in summer $\left(\mathrm{R}^{2}=0.88 ; \mathrm{P}<0.05\right)$, monsoon $\left(\mathrm{R}^{2}=0.81 ; \mathrm{P}<0.05\right)$ and winter $\left(\mathrm{R}^{2}=0.75\right.$; $\mathrm{P}<0.05)$ and humidity in summer $\left(\mathrm{R}^{2}=0.83 ; \mathrm{P}<0.05\right)$, monsoon $\left(\mathrm{R}^{2}=0.79 ; \mathrm{P}<0.05\right)$, and winter $\left(\mathrm{R}^{2}=0.73 ; \mathrm{P}<0.05\right)$ was significantly correlated with population of black kites.

Feeding behavior: We selected six different feeding and foraging area in and around Dhaka city to identify variation of food that consumed by black kites. The results show that intake of different foods by kites depend on situation of feeding and dumping area. Interview with local people $(n=23)$ and direct observation revealed that chicken refuse, beef refuse, fish refuse and carrion at Location-A (Kachukhet dumping sites), human food refuse, garbage and carrion at Location-B (Boliarpur dumping sites) and Location-C (Abdullahpur dumping sites) were the major types of foods consumed by kites in dumping region. Whereas in non-garbage feeding region; insects, rats, fish and earthworms at Location-D (Agricultural field), insects, rats and lizards at Location-E (Botanical garden), human food refuse and small chicks at Location-F (Human habitation) were the major consumed foods. It is interesting to note that black kites were seen to feed on a lizard and small chick only once during study period.

A total of mean number of frequency in successful feeding $(283 \pm 6.21)$ was recorded at six different feeding areas in and around Dhaka city. In garbage based feeding areas, highest feeding rate was recorded in afternoon followed by noon and the lowest rate was observed in morning (Figure 2). Whereas, in non-garbage based feeding areas highest feeding rate was recorded in morning followed by noon and the lowest rate was observed in afternoon (Figure 3). Among four different foraging strategies, food collection by kites standing on the ground and intraspecific cleptoparasitism was never observed during study period. Interspecific cleptoparasitism (against crows) was highest recorded among the foraging strategies followed by flying over the feeding area (Table 4). Similar observation to a study carried out in Kolkata by Mazumdar et al., 2016. Only temperature in summer $\left(\mathrm{R}^{2}=0.69 ; \mathrm{P}<0.05\right)$ and humidity in monsoon $\left(\mathrm{R}^{2}=0.78 ; \mathrm{P}<0.05\right)$ was significantly correlated with mean numbers of successful feeding. On the contrary, temperature in monsoon and winter and humidity in summer and winter were nonsignificant. 
Table 2. Mean $( \pm \mathrm{SE})$ number of black kite, different activity and annual fluctuation in Dhaka city

\begin{tabular}{|c|c|c|c|c|c|c|c|c|}
\hline \multirow{2}{*}{$\begin{array}{r}\text { Transects } \\
\text { name }\end{array}$} & \multirow{2}{*}{$\begin{array}{c}\text { Mean }( \pm \mathrm{SE}) \\
\text { no. of kites }\end{array}$} & \multicolumn{4}{|c|}{ Mean $( \pm$ SE) no. in different activity } & \multicolumn{3}{|c|}{ Annual fluctuation as mean $( \pm \mathrm{SE})$} \\
\hline & & Flying & Roosting & Feeding & Breeding & 2015 & 2016 & 2017 \\
\hline $\mathrm{T}-1$ & $263.4 \pm 7.7$ & $105.25 \pm 8.6$ & $152.7 \pm 11.5$ & $5.37 \pm 8.4$ & 0 & $252 \pm 2.1$ & $294 \pm .7$ & $241 \pm .9$ \\
\hline $\mathrm{T}-2$ & $79.88 \pm 6.01$ & $75.62 \pm 5.93$ & $3.75 \pm 8$ & $0.37 \pm .26$ & $0.125 \pm .12$ & $74 \pm 2.4$ & $121 \pm 6.2$ & $43 \pm .47$ \\
\hline $\mathrm{T}-3$ & $108.12 \pm 6.70$ & $96.62 \pm 11.7$ & $7 \pm .75$ & $4.5 \pm 1.1$ & 0 & $82 \pm .6$ & $167 \pm 5.1$ & $67 \pm .6$ \\
\hline $\mathrm{T}-4$ & $39.12 \pm 2.43$ & $36.5 \pm 4.2$ & $2 \pm .77$ & $0.37 \pm .18$ & $0.25 \pm .16$ & $71 \pm 3.2$ & $82 \pm .3$ & $43 \pm 1.3$ \\
\hline $\mathrm{T}-5$ & $805 \pm 11.88$ & $396.25 \pm 14.04$ & $314.62 \pm 13.3$ & $94.12 \pm 6.92$ & $0.5 \pm .26$ & $609 \pm 4.7$ & $846 \pm 7.1$ & $897 \pm 7.4$ \\
\hline Total & $1296 \pm 5.87$ & $710.25 \pm 3.01$ & $480.16 \pm 6.2$ & $104.76 \pm 3.78$ & $0.88 \pm .33$ & $1088 \pm 4.1$ & $1510 \pm 6.92$ & $1290 \pm 5$ \\
\hline
\end{tabular}

[Transect names: T-1= (Gabtali to Abdullahpur), T-2= (Sadarghat rd), T-3= (Mirpur to Ramna Park), T-4=

(Uttara to Mohakhali), T-5= (Gulistan to Demra)]

Table 3. Relation between black kite population as dependent variables, different activity (flying, roosting, feeding and breeding), and annual fluctuation (2015, 2016 and 2017) as independent variables

\begin{tabular}{c|c|c|c|c|c|c|c|}
\hline & \multicolumn{4}{|l|}{ Different activity } & \multicolumn{3}{l}{ Annual fluctuation } \\
\cline { 2 - 8 } & Flying & Roosting & Feeding & Breeding & 2015 & 2016 & 2017 \\
\hline $\mathrm{R}^{2}$ & 0.97 & 0.95 & 0.95 & $0.54 \mathrm{NS}$ & 0.94 & 0.99 & 0.99 \\
\hline
\end{tabular}

Table 4. Mean ( \pm SE) number of frequency in successful feeding, food taking rate in a day and food taking technique at six different feeding areas in Dhaka city

\begin{tabular}{|c|c|c|c|c|c|c|c|c|}
\hline \multirow{3}{*}{$\begin{array}{l}\text { Sites } \\
\text { name }\end{array}$} & \multirow{3}{*}{$\begin{array}{l}\text { Frequency } \\
\text { in feeding } \\
\text { per day } \\
\text { (n) }\end{array}$} & \multicolumn{3}{|c|}{ Food taking rate in a day } & \multicolumn{4}{|c|}{ Food taking technique } \\
\hline & & \multirow{2}{*}{$\begin{array}{l}\text { Morning } \\
\text { (6:00am- } \\
\text { 10:00am) }\end{array}$} & \multirow{2}{*}{$\begin{array}{l}\text { Noon } \\
\text { (10:00am- } \\
2: 00 \mathrm{pm})\end{array}$} & \multirow{2}{*}{$\begin{array}{l}\text { Afternoon } \\
(2: 00 \mathrm{pm}- \\
6: 00 \mathrm{pm})\end{array}$} & \multicolumn{2}{|c|}{ Autonomous } & \multicolumn{2}{|c|}{ Cleptoparasitism } \\
\hline & & & & & Ground & Flying & $\begin{array}{l}\text { Same } \\
\text { species }\end{array}$ & $\begin{array}{l}\text { Others } \\
\text { species }\end{array}$ \\
\hline L-A & $25.67 \pm 2.33$ & $7.33 \pm 1.2$ & $6 \pm 0.58$ & $12.33 \pm 1.45$ & 0 & $6 \pm 0.58$ & 0 & $19.67 \pm 2.96$ \\
\hline L-B & $15 \pm 1.7$ & $4.67 \pm 0.67$ & $3.33 \pm 0.33$ & $7 \pm 0.58$ & 0 & $3 \pm 0.58$ & 0 & $12 \pm 0.58$ \\
\hline $\mathrm{L}-\mathrm{C}$ & $220 \pm 11.92$ & $58.33 \pm 6.64$ & $74.33 \pm 4.76$ & $88 \pm 4.62$ & 0 & $62.33 \pm 8.37$ & 0 & $157.67 \pm 1.76$ \\
\hline L-D & $12.33 \pm 0.67$ & $8.33 \pm 1.86$ & $2.67 \pm 0.33$ & $1.33 \pm 0.33$ & 0 & $9.33 \pm 1.33$ & 0 & $3 \pm 0.58$ \\
\hline L-E & $4 \pm 0.58$ & $2.67 \pm .33$ & $1.33 \pm 0.33$ & 0 & 0 & $4 \pm 1.15$ & 0 & 0 \\
\hline L-F & $6 \pm 0.58$ & $4 \pm 1.15$ & $1.33 \pm 0.33$ & $0.67 \pm 0.33$ & 0 & $4.67 \pm 0.67$ & 0 & $1.33 \pm 0.33$ \\
\hline & Total $=283 \pm 6.2$ & - & - & - & - & - & - & - \\
\hline
\end{tabular}

[Site names: $\mathrm{L}=$ Location, $\mathrm{L}-\mathrm{A}=$ Kachukhet dumping sites, $\mathrm{L}-\mathrm{B}=$ Boliarpur dumping sites, $\mathrm{L}-\mathrm{C}=$ Abdullahpur dumping sites, $\mathrm{L}-\mathrm{D}=$ Agricultural field, $\mathrm{L}-\mathrm{E}=$ Botanical garden, $\mathrm{L}-\mathrm{F}=$ Human habitation] 


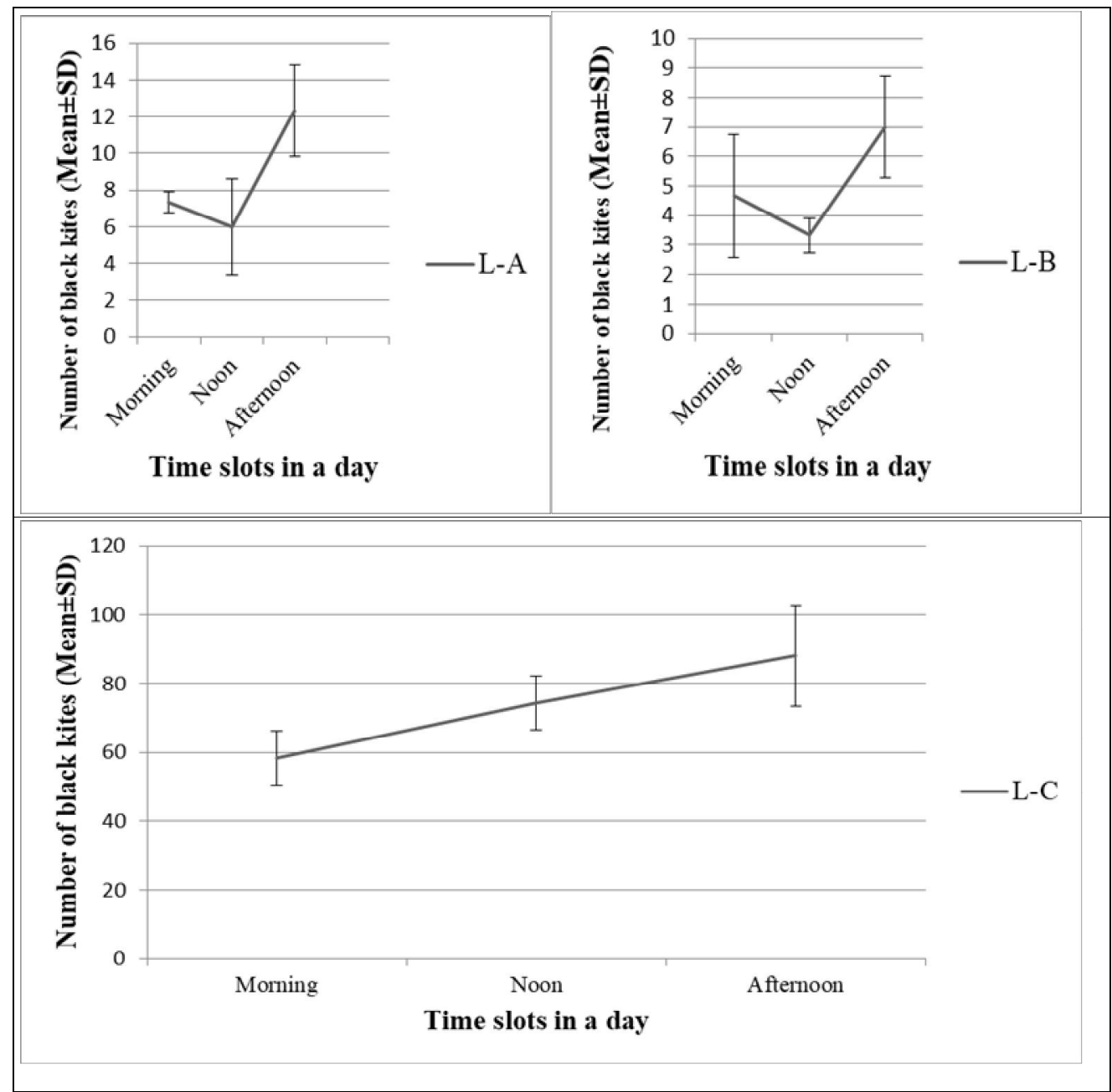

Fig. 2. Successful food taking rate in a day as mean ( $\mathbb{S} \mathrm{SD})$ behind three different garbage based feeding sites (L-A, L-B and L-C) 

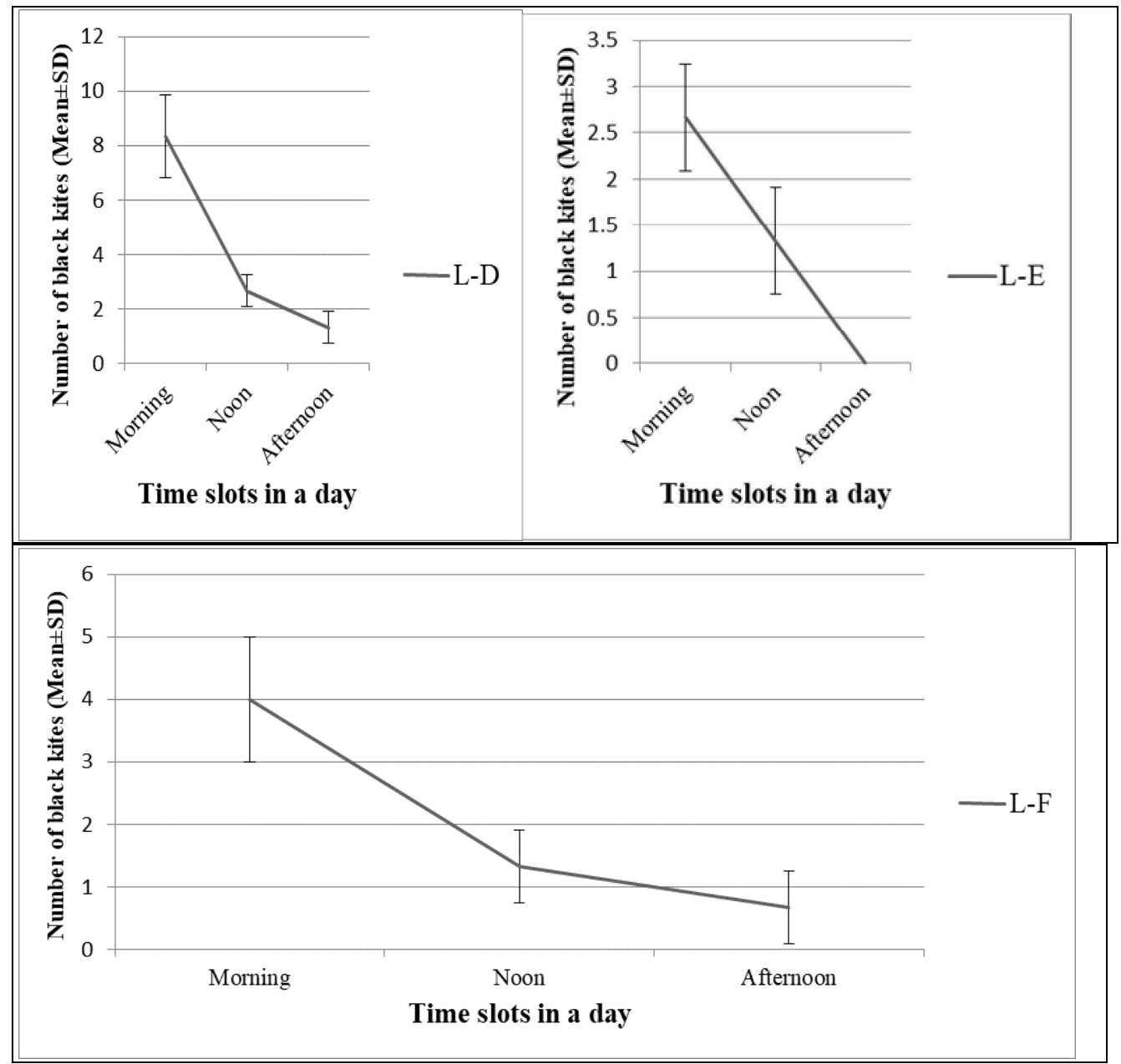

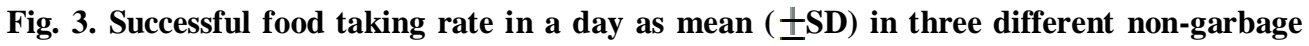
based feeding area (L-D, L-E and L-F)

The black kite (Milvus migrans) is one such resident urban raptor of Indian sub-continent which occurs in large numbers in metro cities (Ali \& Reply, 1968; Mahabal \& Bastawade, 1987). It has been classified as least concerned due to abundant in the area (Bird Life International, 2009). This species has become very common species in the Dhaka city and their soaring and roosting behavior in these areas is a common scene. Besides, this species is also known to form roosting aggregation in study area. Moreover, being a member of family Accipitridae it is a Schedule I species of Wild Life Preservation Amendment Act (1974). In case of raptors, urban habitats have been considered to be of superior quality (Chace \& Walsh, 2006). Species that meet their food requirements within such settings exhibit positive population responses (Sandhya, 2014). 
The raptors play an important role in ecosystems because they can determine the community structure patterns of their prey (Menge et al., 1994).

Raptors are known to cause special problems for the estimation of population status and trends (Fuller \& Mosher, 1981) because they usually disperse in broad regions and/or are secretive species that nest at low densities. The present study revealed that the black kite is distributed throughout the study area and distribution is influenced by availability of food, water and roosting place. Similar observation to a study carried out in India by Naoroji (2007). The black kites are generally seen foraging nearer to garbage dumps (Blanco, 1994; Mazumdar et al., 2018) or agricultural field where they could easily get copious of food in all seasons. A total of 18 feeding, 7 roosting and 7 breeding sites were recorded in study area (Table 1). Although the recording of total number of black kites was approximately thirteen hundred, it seems to be lower in counts for a densely populated city like Dhaka. However, the practice will surely be helpful in future to better design for raptors management. It can be seen from Table 2 that; the highest population was recorded at Transect-5 (Gulistan to Demra dumping station) while lowest population was recorded at Transect-4 (Uttara, Kuril to Mohakhali Bus Terminal). The reason of maximum population was the availability of food and water in the respective site. The largest garbage dump (163.7 acres) in Dhaka city is also located in this site (Transect-5) where majority of raptors fulfill their basic requirement. On the contrary, minimum population at Transect- 4 might be due to the planned urbanization in that area where scarcity of food for black kites was indicated (Figure 1). Agricultural field and Turag River are associated throughout the Transect-1 (Gabtali Bus Terminal, Beribadh to Abdullahpur) and six different feeding areas were recorded in the site where raptors can fulfill their basic demands. Additionally in winter, they are also observed feeding on insects at agricultural field that may not be available when area is flooded with water. The reasons for low population number at rest of the Transect-2 (Gabtali Sweeper Colony, Gabtali-Sadarghat rd to Dhaka University) and Transect-3 (Mirpur 1, Sangsad Bhaban, Tejgaon to Ramna Park) are due to residential area, established urbanization, extreme stressed on vehicles and little number of feeding and roosting places (Figure 1). No serious focus was done on its seasonal variation as well as yearly fluctuation due to lack of time and work force. The population trend are more or less stable during study period. The populations of black kites showed positive relationship with environmental variables like temperature and humidity in all seasons. Environmental parameters and their interactions are thought to shape specific breeding and survival strategies in top predators like raptors. Indirect effects of climate on raptors are probably very remarkable like lessen in food procurement and little predation rate by declining predator availability. The declined status of black kites were reported due to lack of food in a changing landscape and human persecution in Germany (Sabine Hille \& Jean-Marc Tiollay, 2000). The major threats include deforestation and changes in land use pattern, which can affect the abundance, distribution and availability of prey. As a result, abandonment of breeding regions may significant changes in the habitat, such as increased human development and activity (Boeker, 1971; Scott, 1985; Hunt et al., 1999). 
The finding from this study is corroborated with the previous reports where the authors mentioned that, large aggregations of black kites are associated with the abundancy of food (Bernis, 1980; Cramp \& Simmons, 1980; Blanco, 1994, 1997; Giacomo \& Guerrieri, 2008; Iqbal et al., 2015; Sharma \& Soni, 2017). The black kite's diet is one of the best examples, among raptors, within species malleability in foraging strategies and food consumption. In addition, the species evaluated as a scavenger of consume of livestock carrion (Cramp \& Simmons, 1980). Considering food consumption rate of kites100 g/day (www.birdcare.asn.au), $150 \mathrm{~kg}$ of dead and decaying carrion can be carried away every day by the estimated kite's population in the studied area. The number of kites at the dumping sites is almost likely to turn over several times in a span of the day that will eventually accelerate the free scavenging by these raptors. Blanco (1997) stated the availability of kites as city scavenger is of vital importance as they fix up of the decaying carcasses and other scrap heap, which could otherwise fester and lead to augmentation of diseases. To quantify the ecological function of the kites, it will be obligate to tag many individuals, both away and at the scrap heap in future that will transpire their turnover number through the day. In future, the present studies focusing on their foraging strategies on the feeding area will also give better sagacity whether they show fluctuations in number.

The black kites in Dhaka city show a wide range of foraging habits. In addition to the scavenger's role on the dumping sites and roads, these raptors have an important niche in the urban ecosystem as predators (Malhotra, 2007). Our study revealed that the kites preying on insects, fishes, rats, lizards, earthworms and small chicks in non-dumping region. Whereas on the dumping sites they feed on human food refuse, garbage and a byproduct of dressing (chicken refuse, cow refuse and fish refuse). Our findings are bit different than the previous reports where rodents, squirrels, fishes, insects, amphibians, reptiles and birds were mentioned as the main prey (Ferguson-Lees \& Christie, 2001; Malhotra, 2007; Mazumdar et al., 2018). Others reported kites as opportunist hunters and have been known to take birds, bats and rodents (Narayanan, 1989). In an earliest study kites were found to be attracted to smoke and fires to grab escaping prey (Hollands, 1984).

In this study, food consuming rate was highest in afternoon while lowest in morning in garbage based area while opposite phenomenon was observed in non-garbage feeding areas. The reason behind increased food intake in non-garbage feeding areas (agriculture field and garden area) during morning time might be due to more availability of preys like insects in morning than other time of the day. Which were easily captured by raptors while flying over the feeding area. Moreover in morning time, we observed the disposal of various offal substances in outside of the human settlements areas where kites came into close proximity as flying in search of food. The kites were seen to start moving on to the dumping sites gradually from other areas at the time of forenoon during study period. A large aggregation of kites on dumping area results in successful feeding in the afternoon. 
The crows have nearly same feeding habit as kites that occurred interspecific cleptoparasitism against crow population in a dumping area (Sharma \& Soni, 2017). From the present study, it has also been observed that majority of food collection episodes by kites occurred versus crow's populations in studied area. However, no focus was done on successful food collection attempts rate of kites versus crow's population. The present study focuses only successful feeding episodes by kites itself or in opposition to crows was recorded. During our study period, interspecific cleptoparasitism was the highest recorded foraging behavior followed by autonomous (flying) in the study area. Interestingly, autonomous (ground) and intraspecific cleptoparasitism was never observed by the kites. However, several earlier reports stated that these two foraging behaviors were more frequently occurred (De Giacomo \& Guerrieri, 2008; Mazumdar et al., 2016; Sharma \& Soni, 2017).

Lack (1946) stated that, birds time activity budgets are sharply affected by the local environmental variables. Findings from our study are also in agreement with previous study where temperature in summer and humidity in monsoon demonstrated significant relation with successful feeding. In addition, temperature in winter seasonally highly positive correlated and humidity in winter seasonally highly negative correlated with successful feeding. Birds are inclined to wag their energy demands by modifying their behavior, when coping with the environmental variables (Newton, 1979).

Sergio et al. (2003a, b) have successfully patron the use of black kites in Europe as valid conservation model species. The idea of urban ecosystem and wildlife remains disdain in our country. The black kites being a city scavenger and summit trophic level species provide important ecological function to humankind. The kites in study area were found very patient against human intervention during study period. Not only the black kites, but also brahminy kites in study area demonstrated very tolerant behavior against human intervention. We observed the kites roosting on electric power lines, mobile tower, trees and dumping grounds. However, only mobile tower and trees were recorded as nesting place of kites in this study. Though study areas have good population size of kites but cutting of roosting and nesting trees, unplanned urbanization and geometrically expansion in human population caused compression of habitat of black kite which may limit the black kite population. The present study recommends the protection and enhancements of black kite population and its habitat as well as passage of those trees that are usually preferred for roosting and nesting place by black kite. The majority of food demands of black kites come from dumping sites in study area. Therefore, present study recommends we can make region wise lawful small dumping stations in study area for conservation in urban ecosystem.

In addition, it will also be indispensable in justification their role as potential bearers of diseases from such dumps. This qualifies them to be a good model for experimental ecology. These raptors also occur at high densities that make them a valid model species to test ecological hypothesis with higher precision and accuracy. At last, studies validating above concept will establish black kites as an umbrella species for urban ecology (Bird et al., 1996; Luck et al., 2011; Magle et al., 2012). The findings of the 
present study on the distribution and foraging strategies of black kites would be beneficial for future studies and could be used as baseline data of the region studied.

Acknowledgements: The author thanks Dr. M. A. Aziz, Professor, Department of Zoology, Jahangirnagar University for reviewing the manuscript and necessary correction. The author also acknowledge to Olly for help in the data analysis, Babu and Galib for drawing the figure. The author also very grateful to local people and to all the dump personnel for their collaboration during fieldwork.

\section{REFERENCES}

Ali, S. and Ripley, S. D. 1978. Handbook of the Birds of India and Pakistan together with those of Bangladesh, Nepal, Bhutan and Sri Lanka, 2nd ed. Oxford University Press, Delhi. 1: 226-230.

Altman, J. 1974. Observational study of behavior: Sampling methods. Behavior. 49: 227-265.

Bird, D., Varland, D. and Negro, J. 1996. Raptors in Human Landscapes: Adaptations to built and cultivated environments; Raptor Research Foundation; Academic Press, San Diego.

Bird Life International, 2009. "Milvus migrans", IUCN Red List of Treatened Species. Version 2009.2. International Union for Conservation of Naure. Retreived 2010-02-15.

Bernis, F. 1980. La migracion de la saves el Estrecho de Gibraltar. Universided Complutense de Madrid, Madrid, Spain.

Blanco, G. 1994. Seasonal abundance of Black Kites associated with rubbish dump of Madrid, Spain; Journal of Raptor Research; 28(4): 242-245.

Blanco, G. 1997. Role of refuse as food for Migrant, Floater and Breeding Black Kites (Milvus migrans); Journal of Raptor Research; 31 (1):71-76.

Boeker, E. L. and Ray, T. D. 1971. Golden eagle, Aquila chrysaetos population studies in the southwest. Condor, 73, 463-467.

Chace, J. F. and Walsh, J. J. 2006. Urban effects on native avifauna: a review. Landsc. Urban Plan. 74, 46-69.

Cramp, S. C. and Simmons K. E. C. 1980. The birds of the western Palearctic. Oxford Univ. Press, Oxford, UK.

Delibes, M. 1975. Alimentacion del milano negro Milvus migrans en Donana Huelva, Espana. Ardeolo. 21: 183-207.

Daniel, A. 2014. "Using SPSS to Understand Research and Data Analysis". Psychology Curricular Materials. Book 1. http://scholar.valpo.edu/psych_oer/1

Ethier, T. 1993. Survey methods for raptors in British Columbia. Victoria: British Columbia Resource Inventory Committee.

Ferguson-Lees, J. and Christie, D. A. 2001. Raptors of the world; Houghton Miffin Company; New York.

Fuller, M. R. and J. A. Mosher. 1981. Methods of detecting and counting raptors: a review. In Estimating Numbers of Terrestrial Birds, pp. 235-246.Studies in Avian Biology No. 6, Copper ornithological Society, San Francisco.

Fuller, M. R. and Mosher, J. A. 1987. Raptor survey techniques. In G. Pendleton, B. A. Millsap, K. W. Cline, \& D. M. Bird (Eds.), Raptor management techniques manual (pp. 37-65). Washington DC: National Wildlife Federation.

Giacomo, De. U. and Guerrieri, G. 2008. The feeding behaviour of the Black kite Milvus migrans in the rubbish dumpe of Rome. J Raptor Res. 42 (2):110-118. 
Gupta, R. and Kanaujia A. 2011. Breeding biology of pariah kite, Milvus migrans govinda in Jalaun district of Uttar Pradesh, India. Asian J Exp Biol Sci. 2: 679-686.

Hollands, D. 1984. Eagles, Hawks and Falcons of Australia. Nelson, ISBN 0-17-006411-5.

Hunt, W. G., Jackman, R. E., Brown, T. L., Driscoll, D. E. and Culp, L. 1999. A population study of Golden eagle, Aquila chrysaetos in the Altamont pass wind resource area: Population trend analysis 1994-1997. Predatory bird research group, University of California, Santa Cruz, pp. 33.

Iqbal, M. N., Ali, S., Irfan, M., Muhammad, A. and Mujtaba, G. 2015. Population estimation of kites and crows by roost count method in Lahore, Pakistan. Sci Lett 3 (1):27-28.

Lack, D. 1946. Competition for food in birds of prey. Journal of Animal Ecology. 15: 123-129.

Luck, G. W., Davidson, P., Boxall, D. and Smallbone, L. 2011. Relations between Urban Bird and Plant Communities and Human Well-Being and Connection to Nature Conservation Biology, Volume 25, No. 4, 816-826.

Magle, S. B., Hunt, V. M., Vernona, M. and Crooks, K. R., 2012. Urban wildlife research: Past, present, and future, Biological Conservation 155 (2012) 23-32.

Mahabal, A. and Bastawade, D. B. 1985. Population ecology and communal roosting behaviour of Pariah Kite Milvus migrans govinda in Pune (Maharashtra), Journal of the Bombay Natural History Society, 82: 337.

Malhotra, A. K. 2007. Tiger of sky-Pariah Kite, PhD thesis, Shilalekh Publishers, Delhi.

Mazumdar, S. 2013. Ecology and conservation issues of Black Kites Milvus mirgans govinda (Sykes) in Kolkata Municipal Corporation Area (PhD Thesis). Kolkata, India: University of Calcutta.

Mazumdar, S., Ghose, D. and Saha, G. K. 2016. Foraging Strategies of Black Kites (Milvus migrans govinda) in Urban Garbage Dumps. Journal of Ethology. 34 (3), 243-247. DOI 10.1007/s10164-016-0469-5.

Mazumdar, S., Ghose, D. and Saha, G. K. 2017. Communal Roosting Behaviour of Black Kites (Milvus migrans govinda) in an Urban Metropolis. Journal of Ethology, DOI: 10.1007/s10164-017-0516-x.

Mazumdar, S., Ghose, D. and Saha, G.K. 2018. Offal dumping sites influence the relative abundance and roosting site selection of Black Kites (Milvus migrans govinda) in urban landscape: a study from Kolkata metropolis, India. Environmental Monitoring and Assessment, 190:20 DOI: 10.1007/s10661-017-6391-7

Menge, B. A., Berlow, E. L., Blanchette, C. A., Navarrete, S. A. and Yamada, S. B. 1994. The keystone species concept: variation in interaction strength in a rocky intertidal habitat. Ecol. Monogr., 64, 249-286.

Meyer, K. D. 1998. Communal roosts of the American swallow-tailed kite in Florida: habitat associations, critical sites, and a technique for monitoring population status (final report). Florida Game and Fresh Water Fish Commission, Tallahassee

Naoroji, R.K. 2007. Birds of prey of the Indian subcontinent. Om Books International, New Delhi.

Narayanan, E. 1989. Pariah Kite Milvus migrans capturing White breasted Kingfisher Halcyon Smyrnensis. J. Bombay Nat. Hist. Soc., 86(3): 445.

Newton, I. 1979. Population ecology of raptors. Buteo Books, Vermillion.

Pomeroy, D. E. 1975. Birds as scavengers of refuse in Uganda. Ibis 117: 69-81.

Robertson, A. S. and Boshoff, A. F. 1986. The feeding ecology of Cape Vultures Gyps coprotheres in a stock farming Area. BiolConser 35: 63-86.

Sabine, H. and Tiollay, J. M. 2000. "Te imminent extinction of the kites Milvus milvus fasciicauda and Milvus m. migrans on the Cape Verde Islands". Bird Conservation International 10 (4), 361-369. 
Sandhya, V. G. 2014. Ecology of Black Kite (Milvus migrans govinda) with quantification of heavy metals in various tissues. $\mathrm{PhD}$ thesis, The M. S. University of Baroda, Vadodara, India. $182 \mathrm{p}$.

Scott, T. A. 1985. Human impacts on the Golden eagle, Aquila chrysaetos population of San Diego County. M.S. Thesis, San Diego State University, San Diego, California.

Sergio, F., Pedrini, P., and Marchesi, L. 2003a. Reconciling the dichotomy between single species and ecosystem conservation: black kites (Milvus migrans) and eutrophication in pre Alpine lakes; Biological Conservation 110: 101-111.

Sergio F., Pedrini P. and Marchesi L. 2003b. Adaptive selection of foraging and nesting habitat by black kites (Milvus migrans) and its implications for conservation: a multi-scale approach; Biological Conservation 112: 351-362.

Sharma, S. K., and Soni K .C. 2017. Feeding behavior of Indian black kite (Milvus migrans) inhabiting the arid zone of Rajasthan, India. International Journal of Zoology Studies. 5 (2): $58-61$.

Taylor, D. M. 1983. Turkey vultures decline at a traditional roosting site. Great Basin Naturalist 46: 305-306.

Viñuela, J. 1997. Road transects as a large-scale census method for raptors: the case of the Red Kite Milvus milvus in Spain, Bird Study, 44: 2, 155-165. DOI: 10.1080/00063659709461051. 